\title{
Carbon monoxide production in ventilated premature infants weighing less than $1500 \mathrm{~g}$
}

\author{
A F FISCHER, C G OCHIKUBO, H J VREMAN, AND D K STEVENSON
}

Department of Pediatrics, Stanford University School of Medicine, Stanford, California, United States of America

\begin{abstract}
SUMmaRY Mean pulmonary excretion rate of carbon monoxide in 13 premature babies on ventilators was significantly higher $(p<0 \cdot 001)$ than that of 19 healthy infants born at full term. This correlated with carboxyhaemoglobin concentrations in blood, indicating that the premature infants on ventilators produced abnormally large amounts of bilirubin.
\end{abstract}

Exaggerated hyperbilirubinaemia, requiring phototherapy or exchange transfusion, continues to be a common problem complicating the management of very low birth weight premature infants being nursed on ventilators. We have previously reported that healthy premature infants have higher bilirubin production than those born at term ${ }^{1}$ and have shown that there is an association between the pulmonary excretion rate of carbon monoxide $(\mathrm{VeCO})$ and the blood carboxyhemoglobin saturation corrected for inspired carbon monoxide content $\left(\mathrm{HbCO}_{\mathrm{c}}\right){ }^{2}$ Both the $\mathrm{VeCO}$ and the $\mathrm{HbCO}_{c}$ are thought to be suitable indices of bilirubin production. ${ }^{3-5}$ For technical reasons it has not previously been possible to measure the $\mathrm{VeCO}$ of ill very low birthweight premature infants, in particular, those receiving mechanical ventilation. In the present study, the $\mathrm{VeCO}$ was calculated in a group of very low birthweight premature infants who were nursed on ventilators during the first few days of life. The association between the $\mathrm{VeCO}$ and the $\mathrm{HbCO}_{c}$ was also studied.

\section{Patients and methods}

Infants who weighed less than $1500 \mathrm{~g}$ at birth and who were being nursed on ventilators were eligible for the study. Written informed consent was obtained from the parents of each baby.

Ventilatory support varied from infant to infant. All the infants had umbilical artery catheters or peripheral intravenous lines in place so that parenteral fluids could be given. None had haemolytic disease with a positive Coombs' test. The mean (SD) birth weight of the infants was 950 (290) g, and the mean (SD) gestational age was 28 (3) weeks.
The mean (SD) age at which the initial $\mathrm{VeCO}$ calculations were performed was 2 (2) days.

All the infants received ventilatory support from either a Bourns BP200 or a Sechrist Model IV-100B infant ventilator. Both of the units were set up in a time cycled, pressure limited configuration with a constant gas flow of 5-10 litres/minute in the ventilator circuit. Before the gas samples for calculation of the $\mathrm{VeCO}$ were collected the babies breathed a gas mixture that was passed through a Hopcalite converter constucted to fit into the ventilator circuits. This substantially reduced the concentrations of carbon monoxide in the gas entering the ventilators $(<20$ parts per billion), thus improving the sensitivity of the measurement of the carbon monoxide content of the collected samples.

The carbon monoxide content of the gas samples was measured using a gas chromatograph fitted with a column packed with molecular sieve 5A (Altech Associates, Inc., Los Altos, California, USA) and a reduction gas detector (Trace Analytical, Menlo Park, California, USA). VeCO was calculated using the equation:

$$
\operatorname{VeCO}(\mu / \mathrm{kg} / \mathrm{h})=\frac{\left[\mathrm{CO}_{\text {iut }}-\mathrm{CO}_{\text {in }}\right](\mu / /) \times \text { flow }(1 / \mathrm{min}) \times 60(\mathrm{~min} / \mathrm{h})}{\text { Body } \mathrm{Wt}(\mathrm{kg})}
$$

where flow $=$ the flow through the ventilator circuit, $\mathrm{CO}_{\text {out }}=$ the $\mathrm{CO}$ content of the gas in the ventilatory circuit distal to the patient, and $\mathrm{CO}_{\text {in }}=$ the $\mathrm{CO}$ content of the gas in the ventilatory circuit proximal to the patient. The $\mathrm{CO}_{\text {out }}$ and $\mathrm{CO}_{\text {in }}$ gas samples were drawn from the ventilator circuit through a sampling port over two to three minutes so that transient fluctuations in the content of carbon monoxide in the gas flowing through the circuit could be time averaged. Gas leaks in the ventilator circuit were negligible (less than $1 \%$ ). Based on previous measurements of flow volume loops in infants in ventilators, we excluded those subjects with gas leaks around the endotracheal tube which were thought to comprise more than $5 \%$ of that infant's ventilation during the sampling period.

Blood samples $(100 \mu \mathrm{l})$ for calculating $\mathrm{HbCO}$ concentrations were taken 60-75 minutes after the babies began breathing the $\mathrm{CO}$ depleted gas mixture, at the same time as the sampling for the measurement of $\mathrm{VeCO}$. The details of the method 
Table Comparison of mean (SD) estimates of bilirubin production by healthy infants born at term, healthy premature infants, and premature infants on ventilators

\begin{tabular}{|c|c|c|c|c|c|}
\hline & \multicolumn{2}{|c|}{$\begin{array}{l}\text { Healthy infants } \\
\text { born at term }\end{array}$} & \multicolumn{2}{|c|}{$\begin{array}{l}\text { Healthy premature } \\
\text { infants }\end{array}$} & \multirow{2}{*}{$\begin{array}{l}\text { Premature } \\
\text { infants on } \\
\text { ventilators } \\
(n=13)\end{array}$} \\
\hline & $\begin{array}{l}\text { Normal } \\
(n=19)\end{array}$ & $\begin{array}{l}\text { Jaundiced } \\
(n=5)\end{array}$ & $\begin{array}{l}\text { Non-jaundiced } \\
(n=15)\end{array}$ & $\begin{array}{l}\text { Jaundiced } \\
(n=8)\end{array}$ & \\
\hline $\mathrm{Hb}(\mathrm{g} / \mathrm{dl})$ & $19 \cdot 0(2 \cdot 7)$ & $17 \cdot 5(3 \cdot 0)$ & Not done & Not done & $14 \cdot 2(2 \cdot 0) \div$ \\
\hline VeCO $(\mu \mathrm{l} / \mathrm{kg} /$ hour $)$ & $13.4(3.2)^{*}$ & $18 \cdot 5(4 \cdot 5)$ & $15 \cdot 1(4 \cdot 1)$ & $19 \cdot 5(5 \cdot 5)$ & $22 \cdot 8(5 \cdot 5)^{*}+$ \\
\hline $\mathrm{HbCO}_{\mathrm{c}}$ & $0.45(\cdot 13)$ & $0.52(\cdot 10)$ & Not done & Not done & $1.06(.40) \div$ \\
\hline
\end{tabular}

${ }^{*} \mathrm{p}<0.001: t_{\mathrm{p}}<0.001 ; \ddagger \mathrm{HbCO}_{\mathrm{c}}$ and $\mathrm{Hb}$ available on 12 of 13 infants.

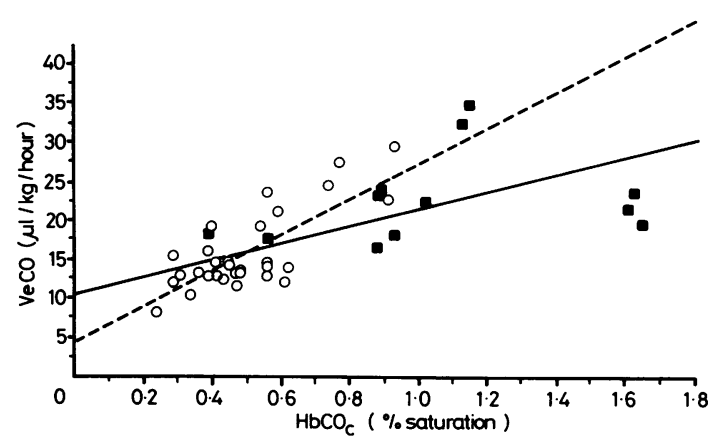

Figure $\mathrm{VeCO} v \mathrm{HbCO}_{c}$ for preterm (ם) and term (O) infants. The regression line for the term infants alone $(---)$ is $\mathrm{VeCO}=23 \cdot 4 \mathrm{HbCO}_{c}+4 \cdot 2$, and the line for both the preterm and term infants combined (-) is $\mathrm{VeCO}=11 \cdot 0 \mathrm{HbCO}+10 \cdot 6$.

for $\mathrm{HbCO}$ analysis have been described previously. ${ }^{6}$ The significance of differences was measured using Student's $t$ test and linear regression analysis.

\section{Results}

In calculating the average $\mathrm{VeCO}, \mathrm{HbCO}_{\mathrm{c}}$, and haemoglobin concentrations for the group, we used only one set of data for each infant. The table summarises the previously reported data on premature infants and those born at full term, and the present data on the very low birthweight premature infants on ventilators.

The figure shows the association between the $\mathrm{VeCO}$ and the $\mathrm{HbCO}_{\mathrm{c}}$. Data for the 30 infants born at full term and the 12 ventilated very low birthweight premature infants for whom both the $\mathrm{VeCO}$ and the $\mathrm{HbCO}_{c}$ were available are presented. The regression line describing these data is $\mathrm{VeCO}=11.0$ $\mathrm{HbCO}_{\mathrm{c}}+10.6(\mathrm{r}=0.65)$. Also presented is the regression line for the 30 infants born at full term alone. The regression line for these data is: $\mathrm{VeCO}=23 \cdot 4 \mathrm{HbCOc}+4 \cdot 2 \quad(\mathrm{r}=0 \cdot 77)$.

Ten of the very low birthweight ventilated preterm infants had blood gas analysis performed (one capillary, nine arterial) at the time of their $\mathrm{VeCO}$ determination. The $\mathrm{PCO}_{2}$ ranged from $4.0-6.5 \mathrm{kPa}$ (mean (SD) $5.5(0.76 \mathrm{kPa})$, and the $\mathrm{PO}_{2}$ ranged from $6 \cdot 3-8 \cdot 8 \mathrm{kPa}$, mean (SD) $7 \cdot 4(0 \cdot 7) \mathrm{kPa})$.

\section{Discussion}

We believe that this report presents the first data on the carbon monoxide excretion rate, as an index of bilirubin production, in very low birthweight premature infants on ventilators. These infants had a mean $\mathrm{VeCO}$ which was significantly higher than that of healthy infants born at full term $(\mathrm{p}<0 \cdot 001)$. The aetiology of this increased rate of carbon monoxide production, which indicates increased production of bilirubin, is not fully understood. Although this study was not designed to identify the specific clinical factors that might contribute to an increase in bilirubin production, it is known that exposure of the fetus to drugs taken by the mother that can affect red cell life span (for example, anaesthetic agents such as bupivacaine), multiple neonatal transfusions of red cells with reduced life span, and an inherent decrease in the life span of fetal red cells are commonly associated with very low birthweight prematurity. The correlation between $\mathrm{VeCO}$ and $\mathrm{HbCO}_{\mathrm{c}}$ reflects greater variability in the association of these indices between the very low birthweight infants on ventilators when compared with infants born at full term.

\section{References}

' Cohen RS, Ostrander CR, Cowan BE, Stevens GB, Hopper AO, Stevenson DK. Pulmonary excretion rates of carbon monoxide, using a modified technique: differences between premature and full-term infants. Biol Neonate 1982;41:289-93.

2 Ostrander CR, Cohen RS, Hopper AO, Cowan BE, Stevens GB, Stevenson DK. Paired determinations of blood carboxyhemoglobin concentration and carbon monoxide excretion rate in term and preterm infants. J Lab Clin Med 1982;100:745-55.

${ }^{3}$ Maisels MJ, Pathak A, Nelson NM, Nathan DG, Smith CA. 
Endogenous production of carbon monoxide in normal and erythroblastic newborn infants. J Clin Invest 1971;50:1-8.

${ }^{4}$ Fallstrom SP. Endogenous formation of carbon monoxide in newborn infants. IV. On the relation between the blood carboxyhemoglobin concentration and the pulmonary climination of carbon monoxide. Acta Paediatr Scand 1968;57:321-9.

${ }^{5}$ Ostrander CR, Johnson JD, Bartoletti AL: Determining the pulmonary excretion rate of carbon monoxide in newborn infants. J Appl Physiol 1976;40:844-8.
6 Vreman HJ, Kwong LK, Stevenson DK. Carbon monoxide in blood: an improved microliter blood-sample collection system with rapid analysis by gas chromotography. Clin Chem 1984:30:1382-6.

Correspondence to Dr D K Stevenson, Department of Pediatrics, S-222, Stanford Medical Center, Stanford, California 94305, USA.

Received 3 March 1987

\title{
Successful suprapubic aspiration of urine
}

\author{
C O’CALLAGHAN* AND P N McDOUGALL
}

Department of Neonatology, The Royal Children's Hospital, Melbourne, Australia, and the *Department of Child Health, University Hospital, Nottingham

SUMMARY When the bladder of neonates requiring suprapubic aspiration of urine was shown to contain urine on ultrasound scanning, suprapubic aspiration was successful on the first attempt in all cases. Without prior scanning only $36 \%$ of first attempts at aspiration were successful.

Accurate diagnosis of urinary tract infection in neonates is important ${ }^{1}$; collection of urine is preferably by suprapubic aspiration, as bag collections are often contaminated. ${ }^{2}$ Unfortunately, suprapubic bladder aspiration, even by experienced medical staff, often requires repeated attempts. This is painful for the infant and may lead to complications such as infection and bowel perforation. This study was performed to assess ultrasound scanning of the bladder as an aid to successful aspiration of urine.

\section{Patients and methods}

The infants studied were from the neonatal intensive and special care units at the Royal Children's Hospital, Melbourne. Forty three consecutive infants requiring suprapubic aspiration of urine as part of their infection screen were studied. Suprapubic aspiration of urine was performed as described by Nelson and Peters. ${ }^{3}$

For 15 of those infants, an ultrasound ATL 300 machine was available and their bladders were scanned for the presence of urine. Aspiration was only attempted if urine was seen on ultrasound scan. If urine was not seen the infant was rescanned at 10-15 minute intervals until it was seen, and only then was aspiration attempted. The other 28 infants required suprapubic aspiration when the ultrasound machine was not available. A record of the number of attempts needed to obtain a sample was made. If after three attempts no urine was obtained, a bag collection was performed.

A further 40 infants not requiring suprapubic aspiration were scanned for the presence of urine in their bladder. If no urine was detected they were rescanned at 10-15 minute intervals until urine was detected.

\section{Results}

Of the 15 neonates scanned by ultrasound prior to aspiration, urine was shown to be present in the bladder within 30 minutes in all cases. Aspiration attempted when urine was seen was successful on all 15 occasions. Of the 28 neonates not scanned, only $10(36 \%)$ had successful aspiration of urine on the first attempt. No urine was obtained despite three attempts at suprapubic aspiration in seven of these infants and bag collection was done instead. Of the 40 neonates scanned at random, $13(33 \%)$ had urine detected within the bladder. Urine was detected in the bladders of all but one of the 27 remaining neonates within 45 minutes.

\section{Discussion}

If the bladder was seen to contain urine on ultrasound scan suprapubic aspiration was successful on the first attempt in all cases. In all but one case urine could be detected within 45 minutes by ultrasound scanning. The infant not showing bladder filling after this period was found to have renal agenesis.

Without scanning, only $36 \%$ of first attempts at suprapubic aspiration were successful. This corre- 